\title{
Looking for Unique Event Venues: An Opportunity for Industrial Heritage Tourism
}

\author{
Ainara Rodríguez-Zulaica* \\ Tourism Department, University of Deusto, Spain
}

Submission: September 17, 2018; Published: October 10, 2018

*Corresponding author: Ainara Rodríguez-Zulaica, Tourism Department, University of Deusto, Bilbao, Spain, Email: ainara.rodriguez@deusto.es

Keywords: Tourism; Heritage; Industry; Water; Electrical power; Lighting; Catering; Audiovisual facilities; Security; Accessibility

\section{Mini Review}

Cities hold yearly thousands of special events. We consider as such "a unique moment in time celebrated with ceremony and ritual to satisfy specific needs" [1]. Special events are a high percentage of the incomes a destination receives from tourism. Events have become so popular that most companies organize meetings, conferences or exhibitions as part of their marketing strategies; and this sums up with all type of cultural and sport events planned throughout the year in most tourist destinations [2]. Nowadays, one of the biggest demands this industry has, is to look for venues that are unique, special and authentic [3]. Even though theatres, exhibition centers, hotels or universities are still the sites that most organizers use to allocate their events [4], we must consider that there is a high demand for new and unusual locations, capable of hosting efficiently a special event.

This is where our study on Industrial Heritage Tourism has focused its attention. Most of the cities in European countries count with industrial buildings that have been abandoned and are waiting for initiatives that allow them to be rehabilitated and reused with a new purpose [5]. Our research shows that, in most cases, as part of processes of urban regeneration, these buildings are being reconverted into multifunctional cultural spaces, that can be used with different purposes. When so, one of these purposes is to be venue for special events. This paper summarizes the results of the research that we are still developing, based in the analysis of the new uses of industrial heritage sites in Western and Northern European countries and its impacts according to the 3-bottom line in the destinations and its inhabitants.

\section{Event Industry's Demand for New Locations}

Event venues are locations where events take place. Some are more common than others; but in the last decades, events have become the center of experiential marketing strategies [6], making us consider the need to look for new non-traditional sites [2]. As Shone \& Parry state, "the key element of all special events is their uniqueness" [7]. When organizing an event, there are many decisions to be taken. However, choosing the venue is probably the one decision with the biggest impact on the event itself [8], as it may be an issue that affects others, such as the date and time, number of attendees or the atmosphere created.

Depending on the desired outcome of the special event being designed, we must consider a list of basic requirements for the venue. Shone \& Parry [7] state that the ease of access and the existence of the necessary equipment and resources for the development of the event are fundamental. They also explain the importance of safety, nearby leisure activities and the infrastructure and superstructure of the destination. But our research focusses its attention only in the physical requirements a venue must comply to be consider a good candidate for hosting events. In this matter, taking as a starting point Monroe's requirements checklist, we can say that a venue must consider:

a. Access, especially in public transport

b. Size and architectural characteristics that allow hosting events, with special attention to floor plans

c. Services available: water, electrical power, lighting, catering, audiovisual facilities, technological facilities such as internet
d. Security
e. Accessibility

Industrial Heritage Tourism: An Opportunity as Unique Event Venues

We have already determined the basic needs organizers look for when searching for new venues for their events. At this point, we want to determine how industrial heritage buildings can be perfect for this purpose. We consider industrial heritage sites those buildings and areas related to the industrial past of a city or region [9-11]. These buildings, mostly abandoned after the different industrial crisis that happened in Europe in the last centuries, confront an uncertain future. If public administrations do not protect them, generally they are being demolished. And 
with such action, part of our history and culture is beginning to disappear [5].

Event tourism can "breathe new life into heritage sites and create more economic and leisure options for locals" [6]. Recent studies highlight how events can help the urban development strategies of cities. Going back to the results of our research, we have analyzed what new uses these industrial sites are having. Up to the moment, we can state that, in Western and Northern European countries, industrial heritage buildings once protected are being reconverted into museums, hotels, or multifunctional cultural spaces. All these sites, in their effort of being open spaces capable of covering different uses, become interesting venues for special events. They meet the basic requirements we mentioned before in this paper and, especially, represent a unique location for any event being organized.

\section{References}

1. Goldblatt Joe (2002) Special Events: Twenty-First Century Global Event Management. John Wiley \& Sons, Inc, New York, USA.

2. Matthews D (2016) Special Event Production: The Process, Second Edition. Routledge, Oxford and New York, UK.
3. Torrents Raimond (2005) Eventos de empresa: el poder de la comunicación en vivo. Ediciones Deusto, Barcelona, Spain.

4. Eventoplus (2016) Informe Eventoplus del Sector MICE en España 2015. Grupo Eventoplus, Madrid, Spain.

5. Pardo Carlos J (2008) Turismo y Patrimonio Industrial. Editorial Síntesis, Madrid, Spain.

6. Ferdinand, Nicole \& Kitchin, Paul J (2016) Events Management. An International Approach. Sage Publishing, London, UK.

7. Shone, Anton \& Parry, Bryn (2004) Successful Event Management. Thomson, London, UK.

8. Getz Donald (2005) Event Management and Event Tourism. Cognizant Communication Corporation, New York, USA.

9. Rodríguez-Zulaica Ainara (2017) Redefiniendo el Concepto de Turismo Industrial. Comparativa de la Terminología en la Literatura Castellana, Francesa y Anglosajona. Revista Pasos 15(2): 311-318.

10. Jago, Leo K Shaw, Robin N (1998) Special Events: A Conceptual and Definitional Framework. Festival Management \& Event Tourism 5: 2132.

11. Monroe, James C (2006) Art of the Event: complete guide to designing and decorating special events. John Wiley \& Sons, Inc, New York, USA.

\section{Your next submission with Juniper Publishers will reach you the below assets}

- Quality Editorial service

- Swift Peer Review

- Reprints availability

- E-prints Service

- Manuscript Podcast for convenient understanding

- Global attainment for your research

- Manuscript accessibility in different formats

( Pdf, E-pub, Full Text, Audio)

- Unceasing customer service

Track the below URL for one-step submission https://juniperpublishers.com/online-submission.php 